\title{
Corporate Disclosure, Ownership Structure And Earnings Management: The Case Of French-Listed Firms
}

Nadia Lakhal, ISG, University of Sousse, Tunisia

\begin{abstract}
The purpose of this paper is to investigate the effect of corporate governance devices on earnings management for French-listed firms. Particularly, it examines the relationship between corporate disclosure practices, ownership structure features and earnings management by French managers. Results show that the relationship between earnings management measures and disclosure scores is negative suggesting that less transparent firms are likely to engage in earnings management practices. The findings also show that families, institutional investors and multiple large shareholders negatively influence earnings management, and hence, act as good corporate governance devices to limit managerial discretion. This paper shed light on the monitoring role of corporate disclosures and ownership structure in the French context where minority shareholders' interests are less protected than in common law countries.
\end{abstract}

Keywords: Corporate Disclosures; Ownership Structure; Earnings Management; French Listed Firms

\section{INTRODUCTION}

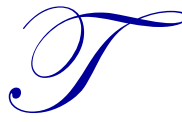

he legendary financial scandals of Enron, WorldCom and Parmalat in the early of the 2000s have involved financial reports manipulation resulting in a growing attention to corporate governance. Earnings management has become a well-researched topic in the accounting literature. Theoretically, the agency theory (Jensen and Meckling, 1976), signalling theory (Ross, 1978) and the positive theory of accounting (Watts and Zimmerman, 1979) explain the use of these accounting strategies. The concern of academics, practitioners and regulators about earnings management is to control managers by introducing a set of corporate governance devices to curb on this phenomenon. On the light of agency theory, controlling mechanisms introduced by shareholders are likely to reduce managerial discretion and agency costs. Among controlling mechanisms are corporate disclosures and ownership structure features.

On the one hand, corporate disclosure is considered as a controlling mechanism likely to reduce conflicts of interests between different stakeholders (Jensen and Meckling, 1976). Corporate disclosures shrink the informational advantage by informed investors and thus the effects of information asymmetry on the cost of capital. This argument is based on the intuition provided by Akerlof (1970). Managers are often faced with the adverse selection problem due to information asymmetry between different market participants. On the other hand, ownership structure is an effective controlling device by large shareholders (Shleifer and Vishny, 1997). Owners of blocks of shares can easily mobilize more resources to monitor managers and protect their investments. Many Researchers, suggest that institutional investors have the opportunity, resources and capacity to monitor and influence the decisions of managers. These investors can control the process of preparing financial statements and prevent managers from behaving in an opportunistic manner, through an aggressive management of earnings, thus ensuring a better quality of accounting information. 
The objective of this study is to examine the relationship between corporate disclosure practices, ownership structure features and earning management in the French listed firms. The French context is worthy to study because of its particular corporate governance environment. Ownership structure of the majority of French companies is concentrated in hands of families. Moreover, the corporate disclosure environment in European companies is less transparent than their Anglo-American counterparts. Our study extends previous research by examining disclosure transparency in an environment of poor investor protection as is the case in France (La Porta et al. 1999). French firms have the possibilities to separate between voting rights and cash flow rights through pyramids, double voting rights shares and crossholding. Due to this complex ownership structures, controlling shareholders have the opportunity to hold more control than their equity ownership indicates, which further amplify the entrenchment effect.

The remainder of this paper is organized as follows: section 2 presents an overview of the literature that deals with corporate disclosure, ownership structure and earnings management. Section 3 describes the sample, data collection and methodology. This is followed by results' analyses and discussion. The last section concludes the paper.

\section{LITERATURE REVIEW AND HYPOTHESES DEVELOPMENT}

\subsection{Corporate Disclosure and Earnings Management}

The relationship between corporate disclosures and earnings management has attracted several researchers in recent years. Since financials scandals, managers are pressured to improve firm transparency. In light of the agency theory, disclosure quality appears to be a solution to agency problems and managerial discretion. The extent of disclosed information, as a controlling device, may reduce the propensity to manipulate accounting earnings because it helps reducing the conflicts of interests. Moreover, corporate disclosure is effective in protecting shareholders and creditors from managerial discretion and minority shareholders from the expropriation risk by controlling shareholders. Voluntary disclosure is also likely to improve the visibility of the firm (Plenborg et al. 2006; Hillegeist and Brow, 2007; and Yonca Ertimur, 2007), reduce the cost of capital and to improve stock market liquidity (Shaw and Wild, 2005, Diamond and Verrecchia, 1991, Easley and O'Hara, 2004, Bushee and Leuz, 2005).

Prior research shows that corporate disclosure help decreasing the informational gap between managers and shareholders (Glosten and Milgrom, 1985; Lang and Lundholm, 1996 among others) and that information asymmetry exacerbates the use of accounting manipulation (Dye, 1988; Trueman and Titman, 1988). Based on a sample of Singaporean firms, Cheng et al. (2004) find a negative relationship between voluntary disclosures and information asymmetry. Corporate disclosures lead then to rich-informational environment and are likely to mitigate earnings management. The empirical study by Lobo and Zhou (2001) confirms the existence of a negative relationship between the extent of corporate disclosures and earnings management through a decrease in information asymmetry. Jo and Kim (2007) argue that earnings management is less evident in more transparent companies. Schipper (1989), Healy and Palepu, (2001) and Schrand and Verrecchia (2004) show that poor informational environment exacerbates managerial discretion. This means that incentives for earnings management are likely to be higher for less transparent firms. Moreover, Lapointe et al. (2006) show that voluntary disclosure and compliance with IAS / IFRS is likely to limit the use of smoothing results. Recently, Latridis (2011) suggests that firms with high disclosure quality are expected to provide stakeholders with reliable information.

The foregoing discussion leads to the first following hypothesis:

$\mathbf{H}_{1}$ : There is a negative relationship between the extent of corporate disclosures and earnings management.

\subsection{Ownership Concentration and Earnings Management}

\subsubsection{Controlling Shareholder and Earnings Management}

The conflicts of interests between large and minority shareholders are driven by ownership concentration and generate high agency costs. The theoretical expropriation hypothesis suggests that the existence of a large 
shareholder can lead to the extraction of private benefits of control by these shareholders at the expense of minority ones (Nenova, 2000; Classens et al. 2000). Empirically, in the Chinese context, Liu et al. (2009) examine the link between controlling shareholders and earnings managers. The authors argue that these shareholders have incentives to manage earnings to expropriate minority shareholders and extract private benefits of control. Their results show that earnings management is related to the incentive to expropriate minority shareholders.

Controlling shareholders are taking advantage of weak protection of minority shareholders interests, especially in countries with low legal protection as is the case of France (LaPorta et al. 1999). These shareholders are deemed to use earnings management practices in order to expropriate minority shareholders (Bhattacharya et al. 2002).

Leuz, Nanda and Wysocki (2003) argue that managers have incentives to manage earnings to hide firm's true performance in order to extract private benefits from outsiders. The authors examine data of 31 countries and find that controlling shareholders can reduce outsiders' interference in their affairs through earnings management. They also show that earnings management is on average higher in code-law countries with low investor protection rights, compared to common-law countries with high investor protection rights.

The preceding discussion leads to the following hypothesis:

$\mathbf{H}_{2}$ : There is a positive relationship between earnings management and the control of the first shareholder.

\subsubsection{Multiple Large Shareholders and Earnings Management}

Another stream of research related to ownership concentration focuses on the percentage of shares held by the second largest shareholder. From the one hand, multiple shareholders will curb on opportunistic behaviour of the first shareholder and protect the rights of minorities. They are then considered as a corporate governance device. From the second hand, a coalition between the first and the second shareholder may occur, leading to minority shareholders' expropriation.

In German companies, Edwards and Weichenrieder (1999) find that the second largest shareholder is considered as a controlling mechanism. According to Guedhami and Mishra, (2009), the existence of multiple large shareholders can achieve valuable internal monitoring. Attig et al. (2008) document that earnings management and multiple large shareholders are negatively associated. Maury and Pajuste (2005) argue that the presence of multiple large shareholders curbs the opportunistic behaviour of shareholders and then enhances information quality.

Finally, Faccio et al. (2001) show that in Europe the second largest shareholder is able to monitor the behaviour of controlling shareholders and limit the expropriation of minority shareholders. By contrast, in Asia, the second-largest shareholder is acting in collusion with the controlling shareholders to extract private benefits at the expense of outside shareholders.

The relationship between earnings management and multiple large shareholders is controversial; this leads to the following hypothesis:

$\mathbf{H}_{3}$ : There is a relationship between control of the second shareholder and earnings management.

\subsection{Shareholder's Type and Earnings Management}

\subsubsection{Institutional Investor's Ownership and Earnings Management}

A growing attention of academic research is related to the role of institutional investors as main corporate governance actors. Numerous authors argue that the involvement of institutional shareholders in monitoring is likely to limit agency problems (Shleifer and Vishney, 1986; Admati et al. 1999; Maug, 1998 and Noe, 2002). Chung, Firth and Kim (2002) indicate that the high concentration of ownership in the hands of institutional investors reduces the opportunistic management of earnings. Rajgopal et al. (2008), Saunders (2006), Liu et al. (2008) and Hadani et 
al. (2011) argue that institutional investors are major actors in managerial control. These authors find a negative relationship between the shares held by institutional investors and earnings management. They conclude that managers are less inclined to manage their earnings due to pressure exerted by institutional investors. Iqbal et al. (2004) also examine the relationship between ownership structure for both managerial and institutional dimensions of 42 British firms between 1991 and 1995. They show that there is a negative relationship between the proportion of institutional investors and discretionary accruals.

be negative:

Hence, the relationship between institutional investors' ownership and earnings management is expected to

$\mathbf{H}_{4}$ : Earnings management is negatively associated with the proportion of shares held by institutional investors.

\subsubsection{Family Ownership and Earnings Management}

According to La Porta et al. (1999) and Faccio and Lang (2003), France is one of those countries in which firms are often dominated by families. Wang (2006) examines the incentives for earnings management by family firms in Japan. The author finds a negative relationship between family ownership and earnings management. Fan and Wong (2002) support the claim that ownership concentration limits the dissemination of accounting information to external investors.

According to the alignment effect hypothesis, families are less likely to engage in earnings manipulation because it can damage family reputation, wealth and long-term performance (Wang, 2006). Ding et al. (2007) find a negative relationship between earnings management and family ownership in Chinese companies in line with the alignment effect hypothesis. In addition, DaDalt et al. (2009), Pozza et al. (2008) and Utama et al. (2008) show that family ownership concentration negatively influences earnings management.

The preceding discussion implies that firms with proportionally greater family control would have lower incentives to engage in earnings management.

$\mathbf{H}_{6}$ : Earnings management is negatively associated with family control ownership.

\section{SAMPLE AND METHODOLOGY}

\subsection{Sample and Data Collection}

Our sample includes French firms listed in the SBF 250's index. We removed 43 financial and insurance firms because they are subject to specific disclosure requirements. The final sample consists of 170 firms in 2008. Data related to disclosure quality and ownership structure were hand-collected from annual reports gathered from the AMF web site. Accounting and financial data were extracted from the Thomson Financial database.

Table 1. Sample of Selection Procedure

\begin{tabular}{lc}
\hline \multicolumn{1}{c}{ Description } & Number of firms \\
\hline Number of firms listed on SBF 250 & 250 \\
Financial and banking firms & 43 \\
Firms with missing financial data & 37 \\
Final sample & 170 \\
\hline
\end{tabular}

\subsection{Methodology}

We use ordinary least squares (OLS) regressions to examine the relationship between earnings management and corporate governance devices. We estimate the following models: 


\section{Model 1:}

$\mathrm{DA}=\mathrm{a}_{0}+\mathrm{a}_{1}($ Dscore $)+\mathrm{a}_{2}(\mathrm{VR} 1)+\mathrm{a}_{3}(\mathrm{IINS})+\mathrm{a}_{4}($ Family $)+\mathrm{a}_{5}($ Audit $)+\mathrm{a}_{6}(\mathrm{ROA})+\mathrm{a}_{7}(\mathrm{MBR})+\mathrm{a}_{8}(\mathrm{LEV})$

Model 2:

$\overline{\mathrm{DA}}=\mathrm{a}_{0}+\mathrm{a}_{1}($ Dscore $)+\mathrm{a}_{2}(\mathrm{VR} 2)+\mathrm{a}_{3}(\mathrm{IINS})+\mathrm{a}_{4}($ LNTA $)+{ }_{\mathrm{a} 5}($ Audit $)+\mathrm{a}_{6}(\mathrm{ROA})+\mathrm{a}_{7}(\mathrm{MBR})+\mathrm{a}_{8}(\mathrm{LEV})$

Model 3:

$\overline{\mathrm{DA}}=\mathrm{a}_{0}+\mathrm{a}_{1}($ Dscore $)+\mathrm{a}_{2}(\mathrm{HI})+\mathrm{a}_{3}($ IINS $)+\mathrm{a}_{4}($ Audit $)+\mathrm{a}_{5}(\mathrm{ROA})+\mathrm{a}_{6}($ MBR $)+\mathrm{a}_{7}(\mathrm{LEV})$

\section{With:}

DA: Discretionnary Accounting

Dscore: Disclosure Score

HI: Herfindahl Index

VR1: Voting rights

IINS: Institutional investors

Family: Family ownership

ROA: Profitability

Audit: Audit Quality

LNTA: Firm Size

MBR: Market to book ratio

LEV: Financial Leverage

\subsection{Variables Measurements}

\subsubsection{Discretionary Accruals}

A measure of discretionary accruals (scaled by total assets) is used as a proxy for earnings management. We use the modified Jones model to estimate the non-discretionary level of total accruals. Hence, our measure of discretionary accruals estimation is the residuals from firm-specific regression of changes in non-cash sales and gross level of property, plant and equipment. In addition, we compute current discretionary accruals using the crosssectional Performance-Adjusted Current Discretionary accruals model developed by Kothari et al. (2005). We use the absolute value of discretionary accruals in our analysis as we have no prior belief to the direction of earnings management.

\subsubsection{Ownership Structure Variables}

Our proxies for ownership concentration rely on Demsetz and Lehn (1985) measures. We use the Herfindahl index, calculated by summing the squared percentages of shares held by each shareholder. We measure institutional investors by the percentage of capital shares held by institutional investors, we introduce a dummy variable for family firms.

\section{Corporate Disclosure Index}

The extent of corporate disclosure is measured by a disclosure index. This index consists of an exhaustive list of items inspired by the work of Wang et al. (2008), Cooke (1989), Meek et al. (1995), Botosan (1997) and Eng and Mak (2003). This list consists of 110 items structured as follows: a strategic component (34 items), another is devoted to non-financial information (39 items), and the third includes all financial information (37 items). The score is the sum of points obtained by the items in an annual report. 


\subsection{Control Variables}

We use a set of firm and industry-specific variables that are deemed to influence earnings management. These variables are gleaned from previous studies and include leverage ratio, market-to-book ratio, firm performance, firm size and audit quality.

Firm size: Prior studies find a negative relation between firm size and earnings management (Yongtae Hoje, 2007). Given their size, large firms are more likely to be under closer scrutiny by outsiders, such as investors or financial analysts, than small firms (Barton and Simko, 2002). However, other studies show that large firms have higher incentives to use accounting discretion to reduce political visibility because they face more political costs (Watts and Zimmerman, 1990; Lee et al. 2007; Zhong et al. 2007). Hence, as the relationship between firm size and earnings management is not conclusive, we do not expect its direction. We use the natural logarithm of total assets to proxy for firm size.

Firm performance: The main objective of earnings management is to distort analysts forecast and to mislead investors by giving them wrong information about a firm's true operating performance. Kasznik (1999) and Haw (2004) find a positive relationship between firm performance and the level of abnormal accruals. However, Jaggi et al. (2009) find a negative coefficient on accounting performance. Hence, we did not expect the direction of the relationship. We use the return on assets ratio to measure firm performance. We include squared ROA as Butler et al. (2004) indicate that the relation between discretionary accruals and profitability may be nonlinear.

Leverage: Harris and Raviv (1991) point out that debt reduces abnormal accruals as the company is subject to financial commitments. Creditors and bankers increase the control of companies with high debt levels in order to inhibit the use of positive discretionary accruals. Jelinek (2007), Lee et al. (2007) find a negative relation between debt and income increasing manipulation. However, when firms are closer to default covenants, managers are more likely to exercise accounting discretion granted by GAAP to prevent violation of these debt covenants (Press and Weintrop, 1990). Since the effect of financial leverage on earnings manipulation is unclear, we do not expect the direction of the relationship. Leverage is measured as the ratio of total debt over total assets.

Audit quality: External auditors exert an influence on earnings management. Audit quality leads the firm to produce more accurate financial statements. High quality audit is often translated into lower accruals level (Francis et al. 1999). The presence of a Big 4 auditor may proxy for audit quality. Previous literature shows a negative association between the presence of Big 4 auditor and earnings manipulation (Bedard et al. 2004; Davidson et al. 2005; Piot and Janin, 2007). Therefore, we expect a negative relationship between audit quality and earnings management.

Growth opportunities: Managers have more incentive to misstate financial reports in order to preserve firm's growth (Summer and Sweeney (1998)). As argued by Chan et al. (2001) and Lui (2004), firms with high growth opportunities have higher valuation ratio because the market uses the dividend discount models to value the firm equity (Lee et al., 2005). High growth opportunities firms are likely to have more private information about these prospects. Therefore, insiders try to reveal this relevant information through financial statements in which earnings have been managed to signal the profitable projects available to the firm (Healy and Palepu, 2003). We expect then the market to book ratio, as a measure of growth opportunities, to be positively related to earnings management.

\section{RESULTS AND DISCUSSION}

\subsection{Univariate Analysis}

Descriptive statistics are provided in Table 2. We notice that the dependent variable measured by discretionary accruals indicates a level of discretionary accruals of 0.0320 . This value is comparable to that obtained by Bozec (2008) for Canadian companies who have found a level of 0.046. Another study was conducted by Haw et al. (2004) found for all Asian companies a level of 0.039 using the model of Jones and the absolute value of discretionary accruals. Lapointe et al. (2006) find a level of 0,053 for Swiss companies. 
Regarding the independent variables, we find that the average score of the level of disclosure in our sample is $43.06 \%$ while the median level of the index is $45 \%$. However, the dispersion of the score is determined by the maximum and the minimum value that is $71 \%$ and $18 \%$ respectively. Table 3 shows that French companies present an average score of strategic information of $11.25 \%, 17.23 \%$ are non-financial information and $14.59 \%$ are financial information. Results also show that the percentage held by the largest shareholder is $37.56 \%$. The ownership structure of French companies is characterized by a shareholder on average much more concentrated than U.S. firms $9.49 \%$ (Bozec, 2008). As for the percentage of shares held by institutional investors, it is on average $21.9 \%$. This result shows that institutional investors are the preferred shareholders of French listed companies. These investors increasingly participate in the ownership of French firms. Furthermore, we notice that $65.3 \%$ of French firms are audited by a "Big-Four" auditor and $33.7 \%$ of them are family Firms.

Table 2. Descriptive statistics

\begin{tabular}{lccccc}
\hline \multicolumn{1}{l}{ Panel A. Continuous variables } & \multicolumn{1}{l}{} \\
\hline Minimum & Maximum & Mean & Median & Std dev. \\
\hline DA & -0.21 & 0.13 & 0.0002 & 0.0009 & 0.051 \\
DScore & 0.04 & 0.36 & 0.1723 & 0.1700 & 0.048 \\
VR1 & 0.01 & 0.97 & 0.37 & 0.3800 & 0.240 \\
VR2 & 0 & 0.97 & 0.4124 & 0.4316 & 0.259 \\
HI & 0.01 & 0.97 & 0.4170 & 0.4568 & 0.241 \\
IINS & 0 & 0.94 & 0.219 & 0.0997 & 0.313 \\
LNTA & 4.06 & 11.73 & 7.8733 & 7.8041 & 1.61319 \\
LEV & 0 & 2.28 & 0.2734 & 0.2253 & 0.25244 \\
MBR & -4.87 & 13.12 & 2.8620 & 2.5100 & 2.07313 \\
ROA & -62.56 & 27.80 & 6.5122 & 6.4000 & 8.38216 \\
\hline
\end{tabular}

\begin{tabular}{lccc}
\hline \multicolumn{2}{l}{ Panel B. Nominal variables } & & \\
\hline Family & & Frequency & Percentage \\
& 1 & 33 & $34.7 \%$ \\
Audit & 0 & 64 & $65.3 \%$ \\
& 1 & 64 & $65.3 \%$ \\
& 0 & 33 & $34.7 \%$ \\
\hline
\end{tabular}

This table indicates descriptive statistics of quantitative variables of 170 firms. DA is the discretionary accruals, DSCORE is the total number of points awarded for corporate disclosure of strategic, non-financial and financial information, VR1 is the sum of voting rights held by the second shareholders, HI is the Herfindahl Index, VR1 is the sum of voting rights held by the first shareholders, Family is a Dummy variable coded 1 if the firm is controlled by a family and 0 otherwise, IINS is the percentage of shares held by institutional investors, MBR is the market-to-book, LNTA is firm size and LEV is total debt to total assets, Auditor is a dummy variable Coded as 1 if auditor is Big-four firm and 0 otherwise and ROA is the profitability of firm.

\subsection{Multivariate Analysis}

Table 3 reports the regression results and shows that the extent of corporate disclosures is negatively related to earnings management. This result supports our first hypothesis and suggests that corporate disclosures improve corporate governance and the effectiveness of management control. Lobo and Zhou (2002), Jo and Kim (2007), Lapointe et al. (2006) have produced similar results. Firm transparency is then considered as a major objective to be achieved to protect outside shareholders' interests because it constrains earnings management as argued by Schrand and Verrecchia (2004). Incentives for earnings management are likely to be higher for companies with less transparent and more pronounced information asymmetry. Our result is therefore in line with agency theory predictions. Corporate disclosures are considered as a controlling device leading to align management interests with shareholders' ones (Jensen and Meckling, 1976). Our finding is also in concordance with the signalling theory predictions suggesting that corporate releases can mitigate information asymmetry between mangers and investors leading to less earnings management practices. 
Table 3 also shows that family ownership is negatively and significantly associated with earnings management. This result is consistent with those find by Wang (2006), Ding et al. (2007), DaDalt et al. (2009), Pozza et al. (2008) and Utama et al. (2008). This finding suggests that family members have little incentives to engage in opportunistic behaviour because this may damage the reputation of the family, its wealth and long-term performance. Furthermore, family shareholders are more concerned with long-term survival of their businesses as they are able to extract private benefits of control at the expense of minority shareholders (Bebchuck, 1999). They have then strong incentive to keep control of their business. Thus, the primary objective pursued by family shareholders is the sustainability of the company in order to transmit the heritage to future generations. By limiting the default risk of their business, they are less likely to manage their earnings.

Table 3 shows a negative relation between earnings management and the multiple larger shareholders. This finding coincides with results of previous work, namely Faccio et al. (2001) suggesting that the second largest shareholder is able to monitor the behaviour of controlling shareholders and to limit the expropriation of minority shareholders leading to decrease earnings management practices.

As for institutional investors, table 5 shows that institutional investor's ownership is negatively associated with earnings management at the $1 \%$ level. This result is consistent with those found by previous literature, namely Rajgopal et al. (2008); Saunders, (2006), Liu et al. (2008); Ping-Sheng Koh, (2007) and Iqbal et al. (2009). The presence of these actors is a guarantee of protection of minority shareholders (Ginglinger and 1'Her, 2002), particularly in civil law countries as is the case of France where minority interests are less protected. Institutional investors have resources to monitor, discipline and influence management decision. In addition, they have privileged access to information. They are then considered as an effective corporate governance device that is likely to reduce earnings management levels.

Finally, our model includes firm characteristics as control variables. The results show that earnings management is negatively associated with firm size. The more the company is small, the more it engages in earnings management practices. This finding is in concordance with those of Jo and Kim (2007), Degeorge et al. 1999, Bozec (2008), Yun and Shin (2004). We also find that well-performed firms are those who engage more in earnings management practices. As for audit quality, as expected the relationship between Big 4 audit and discretionary accruals is negative suggesting that big four auditors are likely to enhance the control of managers by lessening their incentives to manipulate earnings.

Table 3. OLS regression using Jones modified model

\begin{tabular}{|c|c|c|c|c|c|c|}
\hline \multicolumn{7}{|c|}{ DA : Earnings management } \\
\hline & \multicolumn{2}{|c|}{ Model 1} & \multicolumn{2}{|c|}{ Model 2} & \multicolumn{2}{|c|}{ Model 3} \\
\hline & Coef. & t-statistics & Coef & t-statistics & Coef & t-statistics \\
\hline Constant & $0.1285 * * *$ & 5.3 & $0.1198 * * *$ & 6.86 & $0.0935 * * *$ & 4.16 \\
\hline DScore & $-0.007 * * *$ & -4.21 & $-0.0058 * * *$ & -5.94 & $-0.1117 * * *$ & -2.53 \\
\hline VR1 & 0.0104 & 0.78 & & & & \\
\hline VR2 & & & $-0.0603 * *$ & -2.51 & & \\
\hline HI & & & & & 0.0147 & 0.93 \\
\hline IINS & $-0.0273 * *$ & -2.16 & -0.0081 & -0.69 & $-0.0297 * * *$ & -2.33 \\
\hline Family & $-0.007 * * *$ & -3.36 & & & & \\
\hline Audit & -0.0078 & -1.31 & -0.0087 & -1.03 & $-0.0141 *$ & -1.77 \\
\hline LNTA & & & $-0.007 * * *$ & -3.36 & & \\
\hline ROA & $0.0006^{*}$ & 2.17 & $0.0008^{*}$ & 1.84 & $0.0009 * *$ & 1.96 \\
\hline MBR & 0.0022 & 1.13 & 0.0014 & 0.77 & 0.0019 & 0.98 \\
\hline LEV & $-0.0260 *$ & -2.02 & $-0.0332 * *$ & -2.17 & $-0.0345 * *$ & -2.23 \\
\hline $\begin{array}{l}\mathbf{N} \\
\text { Adiusted } \mathbf{R}^{2}\end{array}$ & \multicolumn{2}{|c|}{$\begin{array}{l}170 \\
59.3 \%\end{array}$} & \multicolumn{2}{|c|}{$\begin{array}{l}170 \\
63.23 \%\end{array}$} & \multicolumn{2}{|c|}{$\begin{array}{l}170 \\
47.29 \%\end{array}$} \\
\hline
\end{tabular}

All regressions were run using the ordinary least squares. DA is the discretionary accruals, DScore is the total number of points awarded for corporate disclosure of strategic, non-financial and financial information, VR1 is the sum of voting rights held by the second shareholders, HI is the Herfindahl Index, VR1 is the sum of voting rights held by the first shareholders, Family is a Dummy variable coded 1 if the firm is controlled by a family and 0 otherwise, IINS is the percentage of shares held by institutional investors, MBR is the market-to-book, LNTA is 
firm size and LEV is total debt to total assets, Audit is a dummy variable Coded as 1 if auditor is Big-four firm and 0 otherwise and ROA is the profitability of firm. ***,**, *: t-statistics are significant at the $1 \%, 5 \%$ and $10 \%$ levels, respectively.

\subsection{Robustness Checks}

In this section, we check the reliability of our results by performing several sensitivity tests. We use the performance-adjusted current discretionary accruals model of Kothari et al. (2005) as an alternative measure of earnings management. The results on corporate governance devices remain qualitatively the same.

Table 4. OLS regression using Kothari et al. (2005) model

\begin{tabular}{|c|c|c|c|c|c|c|}
\hline \multicolumn{7}{|c|}{ DA : Earnings management } \\
\hline & \multicolumn{2}{|c|}{ Model 1} & \multicolumn{2}{|c|}{ Model 2} & \multicolumn{2}{|c|}{ Model 3} \\
\hline & Coef. & t-statistics & Coef & t-statistics & Coef & t-statistics \\
\hline Constant & $0.1065^{*}$ & 2.2 & $0.147 * * *$ & 2.94 & $0.1174 * *$ & 2.6 \\
\hline DScore & $-0.044 *$ & -1.83 & 0.01747 & -2.14 & $-0.1124 * * *$ & -2.4 \\
\hline VR1 & 0.0001 & 0.62 & & & & \\
\hline VR2 & & & $-0.062 * * *$ & -2.56 & & \\
\hline HI & & & & & 0.0126 & 0.83 \\
\hline IINS & $-0.006 * * *$ & -3.87 & -0.0064 & -0.54 & $-0.0603 * *$ & -2.51 \\
\hline Family & -0.008 & -1.33 & & & & \\
\hline Audit & $-0.0107 *$ & -1.80 & -0.0174 & -1.12 & $-0.0165^{*}$ & -1.9 \\
\hline LNTA & & & $-0.007 * * *$ & -4.21 & & \\
\hline ROA & $0.0005^{*}$ & 1.84 & $0.0008^{*}$ & 1.82 & $0.0009 * *$ & 1.86 \\
\hline MBR & 0.0023 & 1.18 & 0.0014 & 0.77 & 0.0019 & 0.76 \\
\hline LEV & $-0.027 * *$ & -2.13 & $-0.0332 * *$ & -2.17 & $-0.0345 * *$ & -2.21 \\
\hline $\mathbf{N}$ & & 170 & & 170 & & 170 \\
\hline Adjusted $\mathbf{R}^{2}$ & & $34.32 \%$ & & $33.9 \%$ & & $34.7 \%$ \\
\hline
\end{tabular}

All regressions were run using the ordinary least squares. DA is the discretionary accruals, DScore is the total number of points awarded for corporate disclosure of strategic, non-financial and financial information, VR1 is the sum of voting rights held by the second shareholders, HI is the Herfindahl Index, VR1 is the sum of voting rights held by the first shareholders, Family is a Dummy variable coded 1 if the firm is controlled by a family and 0 otherwise, IINS is the percentage of shares held by institutional investors, MBR is the market-to-book, LNTA is firm size and LEV is total debt to total assets, Audit is a dummy variable Coded as 1 if auditor is Big-four firm and 0 otherwise and ROA is the profitability of firm. ***,**, *: t-statistics are significant at the $1 \%, 5 \%$ and $10 \%$ levels, respectively.

\section{CONCLUSION}

The main purpose of this paper is to show how corporate governance affects earnings management. Particularly, it examines the effect of the extent of corporate disclosures and ownership structure features on earnings management, within the French institutional setting.

Based on a sample of 170 French firms in 2008, we show that the relationship between earnings management measures and the extent of corporate disclosures is negative suggesting that less transparent firms are more likely to engage in earnings management practices. Consistently with previous studies, we show that family and multiple large shareholders negatively influence earnings management and hence, act as good corporate governance devices to limit managerial discretion. Finally, the presence of institutional investors is likely to mitigate earnings management given their ability to monitor and influence managers' decisions. These findings shed the light on the monitoring role of ownership structure and corporate disclosures in the French context where minority shareholders interests are less protected than in common law countries. Future research might extend the scope of this study by using a corporate governance index to measure the quality of corporate governance system of French firms. 


\section{AUTHOR INFORMATION}

Nadia Lakhal Ph.D. is a student in Finance at the University of Sousse (Tunisia). Her major publications include the European Journal of Business and Management. Her special research interests are in corporate governance, corporate disclosure, CEO compensation, earnings quality and gender diversity. E-mail: nadia_lakhal@yahoo.fr

\section{REFERENCES}

Attig, N., Guedhami, O., Mishra, D. (2008), Multiple large shareholders, control contests and implied cost of equity. Journal of Corporate Finance, 14, 721-737.

Bozec, Y. (2008). Concentration de l'actionnariat, séparation des droits de vote et des droits de propriété et gestion des bénéfices: une étude canadienne. Revue canadienne des Sciences de l'Administration, 25(1), 67-82.

Bedard, J., Chtourou, S.M., Courteau, L. (2004). The Effect of Audit Committee Expertise, Independence, and Activity on Aggressive Earnings Management, Auditing. A Journal of Practice and Theory, 23, pp. 13 35 .

Bhattacharya, U., Daouk, M., Welker, M. (2002). The world price of earnings opacity. Working paper, Indiana University.

Boubaker, S., Hind, S. (2011). Multiple large shareholders and earnings informativeness. Review of Accounting and Finance, 10(3), 246-266.

Brian, J. Bushee, C., Leuz (2005). Economic consequences of SEC disclosure regulation: evidence from the OTC bulletin board. Journal of Accounting and Economics, 39, 33-264.

Brown, S. Hillegeist, Stephen, A. (2007). How disclosure quality affects the level of information asymmetry. Review of Accounting Studies, 12, 443 - 477

Bushman, R., Abbie, S. (2001). Financial accounting information and corporate governance. Journal of Accounting and Economics, 32, 237-333.

Butler, M., Leone, A. J., Willenborg M. (2004). An Empirical Analysis of Auditor Reporting and its Association with Abnormal Accruals. Journal of Accounting and Economics, 37, 139-165.

Chang, M., and al. (2008). Does disclosure quality via investor relations affect information asymmetry? Australian Journal of Management, 33(2), 375-390.

Claessens, S., Djankov, S., Lang, L.H.P. (2000). The Separation of Ownership and Control in East Asian Corporations, Journal of Financial Economics, 58, 81-112.

Claessens, S., Djankov, S., Fan, J.P.H., Lang, L.H.P. (2002). Disentangling the incentive and entrenchment effects of large shareholdings. Journal of Finance, 57, 2741-2771.

Dadalt, P., and al, (2009). Does founding family control affect earnings management? Applied Economics Letters, 16 (2), 113-119.

Easley,D., O'hara, M., (2004). Information and the cost of capital. Journal of finance, American Finance Association, 59(4), 1553-1583.

Davidson, R., Goodwin-Stewart, J., Kent, P. (2005). Internal governance structures and earnings management. Accounting and Finance, 45, 241-267.

De Boissieu, C., (2002). Faut-il tout dire, tout le temps? Sociétal, n³7, 3ème trimestre, 76-80.

Dechow, R. M., Sloan, R. G., Sweeney, A. P. (1995). Detecting Earnings Management. The Accounting Review, 70(2), 1993-2025.

Degeorge, F., Patel, J., Zeckhauser, R., (1999). Earnings management to exceed thresholds. Journal of Business, 27, pp. 1-33.

Diamond, D. W., Verrecchia, R. (1991). Disclosure, Liquidity and the Cost of Capital. Journal of Finance, 46(4), 1325-1369.

Ding, Y., Zhang, H., Zhang, J. (2007). Private vs. state ownership and earnings management: Evidence from Chinese listed companies. Corporate Governance: An International Review, 15(2), 223-238.

Eng, L., Mak, Y. (2003). Corporate Governance and Voluntary Disclosure. Journal of Accounting and Public Policy, 22, 325-345.

Ertimur, Y. (2007). Discussion of How disclosure quality affects the level of information asymmetry. Review of Accounting Studies, 12(2-3), 479-485. 
Faccio, M., Lang, L. (2002), The Ultimate Ownership of Western European Corporations, Journal of Financial Economics, 65 (3), 365-395.

Faccio, M., Young, L. (2001), Dividends and Expropriation, American Economic Review, 91, 54-78.

Gabrielsen, G., Gramlich, J., Plenborg, T. (2002). Managerial Ownership, Information Content of Earnings, and Discretionary Accruals in a Non-US Setting. Journal of Business, Finance and Accounting, 29, 967-988.

Gomez, P. (1996). Le Gouvernement de l'Entreprise, Modèles Economiques de l'Entreprise Pratiques de Gestion. Interédition, Masson-Paris, p. 676.

Graham, J.R., Harvey, C.R., Rajgopal, S. (2005). The economic implications of corporate financial reporting. Journal of Accounting and Economics, 40, 3-73.

Gujarati, D. 2004. Basic Econometrics, 4th ed. Montreal: McGraw-Hill

Guedhami, O., Mishra, D. (2009). Excess Control, Corporate Governance, and Implied Cost of Equity. International Evidence, Financial Review, 44, 489-524.

Hadani, M., Goranova, M., Khan, R. (2011). Institutional Investors, Shareholder Activism, and Earnings Management. Journal of Business Research, 64(12), 1352-1360.

Haw, I-M., Hu, B., Hwang, L-S., Wu, W. (2004). Ultimate ownership, income management, and legal and extralegal institutions. Journal of Accounting Research, 42, 423-462

Healy, P., Whalen, J. M. (1999), A Review of the Earnings Management Literature and Its Implications for Standards Setting, Accounting Horizons, 13(4), 365-383.

Healy, P., Palpu, K. (2001). Information asymmetry, corporate disclosure, and the capital markets: A review of the empirical disclosure literature. Journal of Accounting and Economics, 31, 405-440.

Healy, P., Palepu, K. (2001). A review of the empirical disclosure literature. Journal of Accounting and Economics, $31,405-440$.

Holthausen, R. W. and al. (1990). Accounting Method Choice: Opportunistic Behavior, Efficient Contracting and Information Perspective. Journal of Accounting, 12, 207-218.

Huang, P., Zhang Y. (2008). Does Enhanced Disclosure Really Reduce Agency Costs? Evidence from the Value of Corporate Cash Holdings and Dividends. SSRN Working Paper.

Jaggi, B., Leung, S., Gul, F. (2009). Family control, board independence and earnings management: evidence based on Hong Kong firms. Journal of Accounting, and Public Policy, 28 (4), 281-300.

Jelinek, K. (2007). The effect of leverage increases on earnings management. Journal of Business and Economic Studies, 13, 24-46.

Jensen, M. C., Meckling, W. H. (1976). Theory of the firm, managerial behavior, agency costs and ownership structure. Journal of Financial Economics, 3, 305-360.

Jo, H., Kim, Y. (2007), Disclosure frequency and earnings management. Journal of Financial Economics 84, 561 590.

Jones, J. (1991). Earnings Management during Import Relief Investigations. Journal of Accounting Research, 29, 193-228.

Joseph, P. H., Fan and Wong. J. (2002). Corporate Ownership Structure and the Informativeness of Accounting Economics in East Asia. Journal of Accounting and Economies, 33, 401-425.

Kasznik, R. (1999). On the Association between Voluntary Disclosure and Earnings Management. Journal of Accounting Research 37 (1), 57-81.

Kim, O., Verrecchia, R.E. (1994). Market Liquidity and Volume around Earning Announcements. Journal of Accounting and Economics, 17, 41-67.

Kin, Lo, (2008). Earnings management and earnings quality. Journal of Accounting and Economics, 45, 350-357.

Kothari, S. P., Leone, A.J. Wasley, C.E. (2005). Performance Matched Discretionary Accrual Measures. Journal of Accounting and Economics 39, 163-197.

La Porta, R., Shleifer, A., Florencio, L. (1999). Corporate ownership around the world. Journal of Finance, 54, 471517.

Lang, M., Lundholm, R. (1996). Corporate disclosure policy and analyst behavior. The Accounting Review, 71(4), 467-492.

Lapointe P. (2000). Structure De Propriété, Investisseurs Institutionnels Et Performance De L'entreprise. Le Point Des Connaissances, Gestion, 25, 75-86.

Lapointe P., Magnas M. (2003). Les Conseils d'Administration Sont-ils Dupes des Résultats Financiers en Matière de Rémunération des Dirigeants ? Revue du Financier, 139, 7-17. 
Latridis, G. (2011). Accounting disclosures, accounting quality and conditional and unconditional conservatism. International Review of Financial Analysis, 20, 88-102

Leuz, C., Nanda, D., Wysocki, P.D. (2003). Earnings management and investor protection: An international comparison. Journal of Financial Economics, 69, 505-527.

Li Chiu, C. (2009). Do transparency and disclosure predict firm performance? Evidence from the Taiwan market. Expert Systems with Applications, 36(8), 11198-11203

Liu Laura, Y., Peng Emma, Y. (2008). Institutional Investors and Accruals Quality. SSRN Working Paper.

Lobo, Gerald J., Zhou, J. (2001). Disclosure quality and earnings management. Asia-Pacific Journal of Accounting and Economics, 8(1), 1-20

Maury, B., Pajuste, A. (2005). Multiple large shareholders and firm value. Journal of Banking and Finance, 29, $1813-1834$

Noe, T. (2002). Institutional activism and financial market structure. Review of Financial Studies, 15 (1), 289-319.

Petersen C., Plenborg T. (2006). Voluntary disclosure and information asymmetry in Denmark. Journal of International Accounting, Auditing and Taxation, 15, 127-149.

Ping-Sheng, K. (2007). Institutional investor type, earnings management and benchmark beaters. Journal of Accounting and Public Policy, 26, pp. 267-299

Piot, C., Janin, R. (2007). External Auditors, Audit Committees and Earnings Management in France. European Accounting Review, 16 (2), pp. 429-454.

Prencipe, A., Markarian, G., Pozza, L. (2008). Earnings management in family firms: evidence from R\&D cost capitalization in Italy. Family Business Review, 21(1), 71-88

Rajgopal, S., Bowen, Robert. M., Venkatachalam, M. (2008). Accounting Discretion, Corporate Governance and Firm Performance. Contemporary Accounting Research, 25(2), 351-405.

Schipper, K. (1989). Commentary on Earnings management. Accounting horizons, 3, 91-102.

Schrand, C., Verrecchia, R.E. (2004). Disclosure Choice and Cost of Capital: Evidence from Underpricing in Initial Public Offerings. Working Paper, The Wharton School, University of Pennsylvania, Philadelphia, Pennsylvania.

Shleifer, A., Vishny, R. W. (1986). Large Shareholders and Corporate Control. The Journal of Political Economy, 94 (3), 461-488.

Shleifer, A., Vishny, R. W. (1997). A Survey of Corporate Governance. Journal of Finance, 52, 737-783.

Utam, S., Siregar, Veronica S. (2008). Type of earnings management and the effect of ownership structure, firm size, and corporate-governance practices, Evidence from Indonesia. The International Journal of Accounting, 43, 1-27.

Wang, D. (2006). Founding family ownership and earnings quality. Journal of Accounting Research, 44, 619-656

Wang, Y. F., H. C. Yu. (2008), Do restatements really increase substantially after the SOX? How does the stock market react to them? Working Paper, National Chengchi University.

Warfield, T.D., Wild, J.J, Wild, K.L (1995). Managerial ownership, accounting choices, and informativeness of earnings. Journal of Accounting and Economics, 20, pp. 61-91

Watts, R. L., J. L. Zimmerman, J. L. (1978), Towards a Positive Theory of the Determination of Accounting Standards, The Accounting Review, 53, pp. 112-134.

Watts, R., Zimmerman J. (1990). Positive accounting theory: a ten year perspective. The accounting review, 65, 131-156.

Yun, W., Shin H. (2004). Board composition and earnings management in Canada. Journal of Corporate Finance, $10,431-457$

Zhong, K., Gribbin, D, Zheng, X. (2007). The effect of monitoring by outside blockholders on earnings management. Quarterly Journal of Business and Economics, 46, 37-60. 